\title{
The Effectiveness of ICTs Integration in Enhancing Student Motivation in Learning English
}

\author{
Elizabeth Meiske Maythy Lasut*, Jeanette Jeane Bawengan \\ Faculty of Teacher Training and Education \\ Universitas Klabat \\ Airmadidi, Indonesia \\ *elizabethmmlasut@unklab.ac.id,jbawengan@unklab.ac.id
}

\begin{abstract}
Information and communication technologies (ICTs) integration in the classroom in order to make the learning process interesting and meaningful to students is inevitable. It is a challenge for elementary teachers to engage their students in various activities in classroom and to cultivate their willingness in learning new language. This quantitative study attempts to analyze the effectiveness of ICTs integration in fostering students' motivation in learning English. A two-set questionnaire was distributed to students from five private elementary schools in Manado City, North Sulawesi, Indonesia. The collected data were analyzed for descriptive and inferential by using statistical tool, such as frequency, percentage, mean, standard deviation, and simple regression. Findings show that ICTs integration was effectively implemented and students' motivation was high. Moreover, the simple regression analysis revealed that ICTs integration significantly impacts students' motivation in learning English. The results indicate that students' high motivation in learning English resulted when teachers integrate the use of ICTs effectively. Based on the results, it is recommended that students are involved in technology-based learning activities daily, teachers are encouraged to join ICT training program regularly, and schools provide sufficient ICT facilities for all teachers and students.
\end{abstract}

Keywords: ICT integration, effective use of ICT, student learning motivation, English learning

\section{INTRODUCTION}

English language is learnt from basic to high level of education as a foreign language in Indonesia. By the end of school year, students have to master the target language based on the criteria that have been set by Ministry of Education, in order to proceed to the next level of their education. In accomplishing the target, both English teachers and students have to face some obstacles. As a matter of fact, English language is mostly used and practiced by the students only during their school time, within a short period of time, and delivered by using limited tools and facilities. Some research findings revealed that those circumstances led to the decrease of student's interest and motivation in learning English [1, 2]. Young learners tend to easily get bored in learning new knowledge if the things they should learn is delivered by using traditional way of teaching. Teachers should find ways that might get students' attention to study and eventually they are willing to pursue what they want to accomplish in school.

The decision of an individual to realize what he wants is regarded as a motive. Based on the Expectancy-value theory, a person's decision to perform a particular task depends on the belief in the existence of benefits and success in completing the task [3]. The progress of motivation in an individual is characterized by changes in energy that is felt and then is expressed in the form of responses by achieving goals [4]. Educators claim that one important factor in determining student's success or failure in learning new language is their motivation [5]. Learners are motivated to learn when they deal with materials arranged to their level of competency and work with interesting materials. It gives them the reasons to do some actions and efforts to fulfil their desires and needs. To succeed, they have to get more involve with their schoolwork, keen to go to school every day, pay more attention to the lesson, and develop a set of values that stresses the importance of learning for themselves. They also need to be more independent and collaborative as well. Student's motivation in learning English can be seen from their willingness to study more in order to speak English fluently without being nervous, or to be proficient in English for personal prestige [6]. This becomes a challenge for teachers to be the facilitator and to motivate their students to learn English by providing interesting lessons which include information and communication technologies (ICTs) during teaching and learning process

Integration of ICTs in learning generally means a teaching and learning process that is based on the use of technologies in schools. As technology becomes more integrated with every part of human life and the field of education has been influenced by technology, schools must take it seriously the utilization of ICTs to support the teaching and learning process. Teachers and students no longer have to depend solely on printed materials. It was reported that $97 \%$ of elementary and secondary teachers in the U.S has one computer in the classroom, and $99.99 \%$ Japanese schools are equipped with internet accessibility [7]. ICTs are potential in accelerating, strengthening, and helping students for lifelong learning in this information society in disruptive era. Therefore, teachers should be the initiator of ICTs implementation at school. This is intended to increase the quality of education by 
motivation. If the previous studies were conducted to determine factors that ICTs might affect students learning activities based on teachers' perception, this study, however, was attempted to determine its impact to students' motivation based on students' perception. More specifically this study was conducted in an effort to answer the following questions:

RQ1: How effective is the integration of ICT during the learning process?

RQ2: What is the level of student motivation in learning English?

RQ3: Is there a significant effect of ICT integration during the learning process on student motivation in learning English?

The findings are to give adequate information to teachers and schools on how to effectively integrate ICTs in learning so that students would experience meaningful learning process to build their motivation in learning English.

\section{METHODS}

This study utilized the descriptive-causal research designs. The population of this study consisted of elementary students from five Adventist Elementary Schools in Manado City, Indonesia. These schools are owned and operated by the Seventh-day Adventist Church and organized as a single-grade class. The population participated of this study were fifth grade students. The permissions from the school principals involved in the study as well as those of the parents and the fifth year of elementary school were requested. A two-set questionnaire was distributed to 270 fifth grade students, 116 are boys and 154 are girls, as the respondents of this study. During the data gathering, the questionnaires were personally handed to the students and verbal explanation of the purpose of the study was given as well. Since the respondents of the study were young learners, so the researchers constructed the questionnaire in a simple way with only three choices for each question. The students were asked to rate each statement for the ICTs integration and learning motivation inventories, using Likert Scale as follows: 3 (Agree); 2 (Neutral); 1 (Disagree). Moreover, smiley faces were added to attract them to answer the questionnaire. Students were given ample time at their own convenience in completing the questionnaire. 210 respondents out of the 270 completely answered the questionnaire. The collected data were analyzed for descriptive and inferential by using statistical tool, such as frequency, percentage, mean, standard deviation, and simple regression. Students' demographic profiles are shown in Table I based on their gender, in Table II based on the available of ICT resources for use in classroom, and in Table III based on the frequency of ICT use in classroom. development for integrating technology, the fearful for technology glitches, and limited times for setting up the equipment were the barriers that made them reluctant to implement ICTs during teaching and learning activities.

The gaps occurred in those study results triggered the researchers to conduct this study which tried to find out what results ICTs integration might bring to students learning 


\section{A. Students Demographic Profiles}

TABLE I. PERCENTAGE OF RESPONDENTS REGARDING GENDER

\begin{tabular}{|l|l|l|l|l|}
\hline & Frequency & Percent & $\begin{array}{c}\text { Valid } \\
\text { Percent }\end{array}$ & Cum. Percent \\
\hline Boys & 85 & 40.5 & 40.5 & 40.5 \\
\hline Girls & 125 & 59.5 & 59.5 & 100.0 \\
\hline Total & 210 & 100.0 & 100.0 & \\
\hline
\end{tabular}

From the table 1 above, of the 210 respondents, 125 or $59.5 \%$ of the respondents are girls, and 85 or $40,5 \%$ are boys. This implies that there were more girls than boys.

TABLE II. The AVAIABLE OF ICT RESOURCES FoR Use IN CLASSROOM

\begin{tabular}{|l|l|l|}
\hline & Frequency & Percent \\
\hline Tape Recorder & 39 & 18.6 \\
\hline Video + Laptop & 41 & 19.5 \\
\hline Video + Laptop + Power point & 130 & 61.9 \\
\hline
\end{tabular}

Table 2 shows the available ICT resources for use in classroom. The results showed that 130 or $61.9 \%$ of the respondents admitted that video, laptop and power point presentation were used during teaching and learning process. However, 41 or $19.5 \%$ of the respondents admitted that video and laptop were used, and only 39 or $18.6 \%$ of the respondents admitted that none resources were used, except tape recorder.

TABLE III. THE FREQUENCY OF ICT USE IN CLASSROOM

\begin{tabular}{|l|l|l|l|l|l|}
\hline \multicolumn{2}{|c|}{} & Freq. & Percent & $\begin{array}{c}\text { Valid } \\
\text { Percent }\end{array}$ & Cum. Percent \\
\hline \multirow{4}{*}{ Valid } & once a week & 15 & 7.1 & 7.1 & 7.1 \\
\cline { 2 - 6 } & twice a week & 36 & 17.1 & 17.1 & 23.4 \\
\cline { 2 - 6 } & three times a week & 112 & 53.3 & 53.3 & 77.6 \\
\cline { 2 - 6 } & every day & 47 & 22.4 & 22.4 & 100.0 \\
\cline { 2 - 6 } & Total & 210 & 100.0 & 100.0 & \\
\hline
\end{tabular}

As presented in table 3,112 or $53.3 \%$ of respondents admitted that it is "three times a week" that ICT was used in the classroom. Only 15 or $7.1 \%$ of respondents experienced the ICT use "once" in a week.

\section{RESULTS AND DISCUSSION}

Research results and data analysis were discussed based on the research questions, and in the light of the previous studies.

\section{A. The Level of ICT Integration}

TABLE IV. FREQUENCY AND MEAN SCORE OF ICT INTEGRATION

\begin{tabular}{|l|l|l|l|l|l|}
\hline $\begin{array}{c}\text { I think that ICT } \\
\text { use in classroom } \\
\ldots .\end{array}$ & $\begin{array}{c}\text { Dis- } \\
\text { agree }\end{array}$ & Neutral & Agree & M & S.D \\
\hline $\begin{array}{l}\text { Make the lessons } \\
\text { interesting }\end{array}$ & $1(.5 \%)$ & $28(13.3 \%)$ & $161(86.2 \%)$ & 2.86 & 0.36 \\
\hline $\begin{array}{l}\text { Help me learn new } \\
\text { vocabulary }\end{array}$ & $4(1.9 \%)$ & $24(11.4 \%)$ & $182(86.7 \%)$ & 2.85 & 0.41 \\
\hline $\begin{array}{l}\text { Make the lesson easy } \\
\text { to be understood }\end{array}$ & $\begin{array}{l}16 \\
(7.6 \%)\end{array}$ & $50(23.8 \%)$ & $144(68.6 \%)$ & 2.61 & 0.63 \\
\hline Help me learn better & $8(3.8 \%)$ & $30(14.3 \%)$ & $172(81.9 \%)$ & 2.78 & 0.50 \\
\hline $\begin{array}{l}\text { Help me improve my } \\
\text { reding skill }\end{array}$ & $7(3.3 \%)$ & $43(20.5 \%)$ & $160(76.2 \%)$ & 2.73 & 0.52 \\
\hline
\end{tabular}

Table 4. Cont.

\begin{tabular}{|c|c|c|c|c|c|}
\hline $\begin{array}{l}\text { Make the lesson } \\
\text { seems real }\end{array}$ & $\begin{array}{l}31 \\
(14.8 \%)\end{array}$ & $12(15.7 \%)$ & $167(79.5 \%)$ & 2.65 & 0.73 \\
\hline $\begin{array}{l}\text { Help me correct my } \\
\text { false pronunciation }\end{array}$ & $6(2.9 \%)$ & $64(25.7 \%)$ & $150(71.4)$ & 2.69 & 0.52 \\
\hline $\begin{array}{l}\text { Help me remember } \\
\text { the lesson }\end{array}$ & $4(1.9 \%)$ & $37(17.6 \%)$ & $169(80.5 \%)$ & 2.79 & 0.46 \\
\hline $\begin{array}{l}\text { Make me know how } \\
\text { to use technology }\end{array}$ & $\begin{array}{l}16 \\
(7.6 \%)\end{array}$ & $9(4.3 \%)$ & $185(88.1 \%)$ & 2.81 & 0.56 \\
\hline $\begin{array}{ll}\begin{array}{l}\text { Broaden } \\
\text { knowledge }\end{array} & \text { my } \\
\end{array}$ & $5(2.4 \%)$ & $22(10.5 \%)$ & $183(87.1 \%)$ & 2.85 & 0.42 \\
\hline Make me smart & $5(2.4 \%)$ & $19(9.0 \%)$ & $186(88.6)$ & 2.86 & 0.41 \\
\hline $\begin{array}{l}\text { Make teacher's } \\
\text { explanation clear }\end{array}$ & $7(3.3 \%)$ & $23(11.0 \%)$ & $180(85.7 \%)$ & 2.82 & 0.46 \\
\hline $\begin{array}{l}\text { Make the instruction } \\
\text { clear }\end{array}$ & $7(3.3 \%)$ & $18(8.6 \%)$ & $185(88.1 \%)$ & 2.85 & 0.44 \\
\hline Make me active & $1(.5 \%)$ & $54(25.7 \%)$ & $155(73.8 \%)$ & 2.73 & 0.45 \\
\hline Lessen my anxiety & $3(1.4 \%)$ & $16(7.6 \%)$ & $191(91.0 \%)$ & 2.90 & 0.35 \\
\hline \multicolumn{4}{|l|}{ Overall } & 2.89 & 0.32 \\
\hline
\end{tabular}

Table 4 shows the frequency and mean score of ICT integration based on what students experienced in the classroom. The results show that students think ICTs use in the classroom have successfully lessen their anxiety $(M=2.90)$, and made the lessons interesting $(\mathrm{M}=2.86)$. They also think that ICT made them smart ( $M=2.86)$ because ICTs use helped them to learn new vocabulary $(\mathrm{M}=2.85)$ which was clearly instructed and explained by the teacher $(\mathrm{M}=2.85)$ by using ICT. The previous results were rated as the highest five. The results which show that the students think ICT use in the classroom helped them to correct their false pronunciation $(\mathrm{M}=2.65)$ and made the lesson seems real $(M=2.61)$ were rated the lowest. All of these factors have influenced the overall mean score on ICT integration, which is 2.89 , indicating that as an overall ICT integration was effectively implemented by the teachers.

\section{B. The Level of Students Motivation in Learning English}

TABLE V. FREQUENCY AND MEAN SCORE OF STUDENT MOTIVATION IN LEARNING ENGLISH

\begin{tabular}{|l|l|l|l|l|l|}
\hline $\begin{array}{l}\text { In English class } \\
\text { I ... }\end{array}$ & $\begin{array}{c}\text { Dis- } \\
\text { agree }\end{array}$ & Neutral & Agree & Mean & S.D \\
\hline Enjoy the lesson & $5(2.4 \%)$ & $\begin{array}{l}30 \\
(14.3 \%)\end{array}$ & $\begin{array}{l}175 \\
(83.3 \%)\end{array}$ & 2.81 & 0.45 \\
\hline $\begin{array}{l}\text { Pay attention to } \\
\text { the lesson }\end{array}$ & $9(4.3 \%)$ & $\begin{array}{l}35 \\
(16.7 \%)\end{array}$ & $\begin{array}{l}166 \\
(79.0 \%)\end{array}$ & 2.75 & 0.53 \\
\hline $\begin{array}{l}\text { Like to give my } \\
\text { opinions }\end{array}$ & $\begin{array}{l}24 \\
(11.4 \%)\end{array}$ & $9(4.3 \%)$ & $\begin{array}{l}177 \\
(84.3 \%)\end{array}$ & 2.73 & 0.66 \\
\hline $\begin{array}{l}\text { Do my task } \\
\text { diligently }\end{array}$ & $6(2.9 \%)$ & $\begin{array}{l}25 \\
(11.9 \%)\end{array}$ & $\begin{array}{l}179 \\
(85.2 \%)\end{array}$ & 2.82 & 0.45 \\
\hline $\begin{array}{l}\text { Do not hesitate } \\
\text { to finish my } \\
\text { work }\end{array}$ & $6(2.9 \%)$ & $\begin{array}{l}38 \\
(18.1 \%)\end{array}$ & $\begin{array}{l}166 \\
(79.0 \%)\end{array}$ & 2.76 & 0.49 \\
\hline $\begin{array}{l}\text { Try to practice } \\
\text { my English }\end{array}$ & $7(3.3 \%)$ & $\begin{array}{l}31 \\
(14.8 \%)\end{array}$ & $\begin{array}{l}172 \\
(81.9 \%)\end{array}$ & 2.79 & 0.486 \\
\hline Ask questions & $8(3.8 \%)$ & $\begin{array}{l}51 \\
(24.3 \%)\end{array}$ & $\begin{array}{l}151 \\
(71.9 \%)\end{array}$ & 2.68 & 0.54 \\
\hline $\begin{array}{l}\text { Submit the } \\
\text { homework on } \\
\text { time }\end{array}$ & $7(3.3 \%)$ & $\begin{array}{l}27 \\
(12.9 \%)\end{array}$ & $\begin{array}{l}176 \\
(83.8)\end{array}$ & 2.8 & 0.47 \\
\hline $\begin{array}{l}\text { Feel } \\
\text { comfortable }\end{array}$ & $6(2.9 \%)$ & $\begin{array}{l}51 \\
(24.3 \%)\end{array}$ & $\begin{array}{l}153 \\
(72.9 \%)\end{array}$ & 2.7 & 0.52 \\
\hline $\begin{array}{l}\text { Like to perform } \\
\text { a task }\end{array}$ & $7(3.3 \%)$ & $\begin{array}{l}23 \\
(11.0 \%)\end{array}$ & $\begin{array}{l}180 \\
(85.7 \%)\end{array}$ & 2.82 & 0.46 \\
\hline
\end{tabular}


Table 5. Cont.

\begin{tabular}{|l|l|l|l|l|l|}
\hline $\begin{array}{l}\text { Want to be } \\
\text { involved in } \\
\text { group work }\end{array}$ & $9(4.3 \%)$ & $\begin{array}{l}23 \\
(11.0 \%)\end{array}$ & $\begin{array}{l}178 \\
(84.8 \%)\end{array}$ & 2.81 & 0.49 \\
\hline $\begin{array}{l}\text { Do not want to } \\
\text { miss the lesson }\end{array}$ & $\begin{array}{l}19 \\
(9.0 \%)\end{array}$ & $\begin{array}{l}10 \\
(4.8 \%)\end{array}$ & $\begin{array}{l}181 \\
(86.2 \%)\end{array}$ & 2.77 & 0.6 \\
\hline $\begin{array}{l}\text { Eager to answer } \\
\text { questions }\end{array}$ & $7(3.3 \%)$ & $\begin{array}{l}25 \\
(11.9 \%)\end{array}$ & $\begin{array}{l}178 \\
(84.8 \%)\end{array}$ & 2.81 & 0.47 \\
\hline $\begin{array}{l}\text { Want to be a } \\
\text { good student }\end{array}$ & $3(1.4 \%)$ & $\begin{array}{l}32 \\
(15.2 \%)\end{array}$ & $\begin{array}{l}175 \\
(83.3 \%)\end{array}$ & 2.82 & 0.42 \\
\hline \multicolumn{7}{|l|}{ Overall } & 2.85 & 0.37 \\
\hline
\end{tabular}

Table 5 shows the frequency and mean score of students' motivation in learning English. The results show that while learning English students want to be good students $(\mathrm{M}=2.82)$, and like to perform a task $(\mathrm{M}=2.82)$. They also admitted that they do their tasks diligently $(M=2.82)$ because they enjoy the lesson $(\mathrm{M}=2.81)$ and wanted to be involved in group work activity $(M=2.81)$. Moreover, students' motivation in learning English was shown by their eagerness to answer questions addressed by the teacher $(\mathrm{M}=2.81)$. The previous results were rated as the highest six. However, the result also shows that asking questions during the lesson was the least activity students would do during the lesson $(\mathrm{M}=2.68)$ which was rated as the lowest mean score. All of these factors have influenced the overall mean score on students' motivation in learning English, which is 2.85, indicating that as an overall students' motivation in learning English was high.

\section{The Effectiveness of ICTs Integration to Students Motivation in Learning English}

In this study, simple regression is used to test the hypothesis developed by the researchers. The test is used to answer research question that aimed to determine the effect of ICT integration to students' motivation in learning English.

Table 6 presents the effect of ICT integration to students' motivation in learning English. As presented in Table V, ICT integration was found to be statistically significant to students' motivation in learning English ( $\mathrm{sig}=0.025<0.05)$. The direction of the relationship between variables was positive, implying that the more effective of ICT integration, the higher is students' motivation in learning English. From Table 6, it shows that the increasing of 1 level of the effectiveness of ICT integration will elevate 0.868 of students' motivation level. Therefore, the null hypothesis stating that there is no significant effect of ICT integration to students' motivation in learning English is "rejected".

TABLE VI. THE EFFECTIVENESS OF ICT INTEGRATION TO STUDENT MOTIVATION IN LEARNING ENGLISH

\begin{tabular}{|l|l|l|l|l|l|}
\hline \multicolumn{1}{|c|}{ Model } & \multicolumn{2}{|c|}{$\begin{array}{c}\text { Unstandardized } \\
\text { Coefficients }\end{array}$} & $\begin{array}{c}\text { Standardized } \\
\text { Coefficients }\end{array}$ & \multirow{2}{*}{ Sig. } & \\
\cline { 2 - 4 } & \multicolumn{1}{|c|}{ Std. Error } & \multicolumn{2}{|c|}{ Beta } & & \\
\hline (Constant) & .347 & .154 & & 2.256 & .025 \\
\hline $\begin{array}{l}\text { ICT } \\
\text { Integration }\end{array}$ & .868 & .053 & .751 & 16.397 & .000 \\
\hline
\end{tabular}

TABLE VII. THE CORRELATION BETWEEN THE EFFECTIVENESS OF ICT INTEGRATION AND STUDENTS’ MOTIVATION IN LEARNING ENGLISH

\begin{tabular}{|l|c|l|l|l|}
\hline Model & R & R Square & $\begin{array}{c}\text { Adjusted R } \\
\text { Square }\end{array}$ & $\begin{array}{c}\text { Std. Error of the } \\
\text { Estimate }\end{array}$ \\
\hline 1 & $.751^{\mathrm{a}}$ & .564 & .562 & .21113 \\
\hline \multicolumn{5}{|c|}{ a. Predictors: (Constant), Learning Motivation }
\end{tabular}

Table 7 shows that the correlation between the effectiveness of ICT integration and students' motivation in learning English was 0.751, with Coefficients Determinant $56.4 \%$. This means that $56.4 \%$ of students' motivation in learning English was affected by the effectiveness of ICT integration, while the other $43.6 \%$ was determined by other variable which was not included in this study.

\section{CONCLUSION}

This study enlightened the effectiveness of ICT integration in teaching and learning based on what students have experienced at Adventist Elementary Schools in their daily classroom activities. Even though the number and type of ICT resources were limited, still the ICT was effectively integrated by teachers. Teachers at Adventist Elementary Schools in Manado were able to maximize the use of ICT in classroom activity, based on the frequency and time spent of ICT use. Students experienced the benefits of ICT use when teaching and learning takes place. They experienced the excitement and felt the improvement of their skills and knowledge in English language. The classroom learning activities they experienced has elevated their motivation in learning English because they were involved in technology-based learning activities daily. This would be the new experience for them that triggered their curiosity. Knowing that plenty advantages can ICT deliver, it would be necessary for all school principals to make it available for all teachers to have sufficient ICT facilities in their classroom, and to encourage all teachers to integrate the ICT in teaching and learning activity effectively. This can be accomplished by giving the chance for all teachers to equip themselves with the skills and knowledge in ICT by joining the ICT training program regularly.

\section{ACKNOWLEDGMENT}

Our sincere gratitude goes to Kementerian Riset dan Teknologi Republic of Indonesia for their generosity to financially support us in doing this study. We would like to thank Mr. Marthen Sengkey, Ph. D, the President of Universitas Klabat, for his valuable advice. We would like also to thank the editor of Atlantis Press for their advice on the revision of this article. Our high appreciation also goes to Adventist Elementary School Principals for giving us permission to conduct the study at their institutions, and all students for their great contribution as participants in this study.

\section{REFERENCES}

[1] S.S.C. Young, "Integrating ICT into second language education in a vocational high school", J Comput Assist Learn, 2003.

[2] M. Meshkat, and M. Hassani, "Demotivating factors in learning english: The case of Iran", In: Procedia - Social and Behavioral Sciences, 2012. 
[9] S. Ghavifekr, A. Razak, M. Ghani, N. Ran, Y. Meixi, and Z. Tengyue, "ICT Integration in Education: Incorporation for Teaching \& Learning Improvement”, Malaysian Online J Educ Technol, 2014.

[10] T. Plomp, W.J. Pelgrum, and N. Law, "SITES2006-international comparative survey of pedagogical practices and ICT in education", In: Education and Information Technologies, 2007.

[11] M.J. Cox, and G. Marshall, "Effects of ICT: Do we know what we should know?", In: Education and Information Technologies, 2007.

[12] K. Kusano, et al., "The Effects of ICT Environment on Teachers' Attitudes and Technology Integration in Japan and the U.S”, J Inf Technol Educ Innov Pract, 2013. 